\title{
A New Acridine-Imidazolium-Based Cholestane Receptor for Anion Sensing ${ }^{\dagger}$
}

\author{
Jyoti Ramesh Jadhav, Md. Wasi Ahmad, and Hong-Seok Kim*

\begin{abstract}
Department of Applied Chemistry, Kyungpook National University, Daegu 702-701, Korea. *E-mail: kimhs@knu.ac.kr
\end{abstract} \\ Received February 25, 2011, Accepted March 2, 2011
}

\begin{abstract}
A new highly selective receptor (3) based on an acridine-imidazolium functionalized cholestane for anion sensing was designed and synthesized. A binding study of $\mathbf{3}$ with various anions was assessed by UV-vis and fluorescence spectroscopies in dry $\mathrm{CH}_{3} \mathrm{CN}$. Receptor 3 showed the highest selectivity toward hydrogen pyrophosphate $\left(\mathrm{Ka}=1.5 \times 10^{4} \mathrm{M}^{-1}\right)$.
\end{abstract}

Key Words : Fluorescence sensing, Acridine, Imidazolium, Hydrogen pyrophosphate, 3,7-Diaminocholestane

\section{Introduction}

Over last few decades enormous advances have taken place in the field of supramolecular chemistry, particularly in anion recognition and fluorescence sensing, which have become fast growing fields of research area due to their numerous fundamentals roles in a range of chemical, biological, and environmental processes. ${ }^{1}$ Selective binding of anions by a host molecule depends upon the size and geometry of the anions as well as the host molecule. Challenging developments in this area have also led to the development of a variety of host molecules containing imidazolium moieties. ${ }^{2}$ Imidazolium functionalized complexes have recently gained a great deal of attention due to many of their derivatives being capable of binding anions through strong and unique (C$\mathrm{H})^{+\ldots} \mathrm{X}^{-}$hydrogen bonds between the imidazolium moieties and various anions.

Steroids offer several attractive features that allow them to be used as building blocks in the construction of molecular receptors. $^{3}$ One distinct advantage is their high degree of preorganization when they inserted into a receptor, because the rigid steroid frame enforces a preorganized binding site and provides a high degree of homogeneity. Cholesterol is an essential metabolite required for major biological functions, such as the cell membrane structure where the steroid forms. ${ }^{4}$ It also provides the structural scaffolding for the synthesis of steroids and hormones, and for the biosynthesis of bile and bile acid salts. ${ }^{5}$ Cholesterol-based receptors are the least synthesized and used in supramolecular chemistry due to their limited usefulness by their low degree of functionalization. Our main aim was to design and synthesize receptors functionalized in the C-3 and C-7 positions of $5 \alpha$-cholestane with amino groups for molecular recognition. For that, we have also described several methods for preparation of amine compounds through reductive amination. ${ }^{6}$ The $5 \alpha$-skeleton of cholestane provides more space between the functionalized positions at C-3 and C-7, and introduction of the axial 3- and 7-NH groups provide the two necessary inwardly directed hydrogen bonding sites. ${ }^{7}$ We have also synthesized novel cholestane-based receptors containing amide, ${ }^{8}$ and imidazole $(\mathbf{1})^{9}$ as recognizing pendants at the 3 and 7postions of $5 \alpha$-cholestane for anions and dicarboxylic acid recognition. These were evaluated by an ${ }^{1} \mathrm{H}$ NMR study. Recently, cholestane-based fluorescent imidazolium receptor
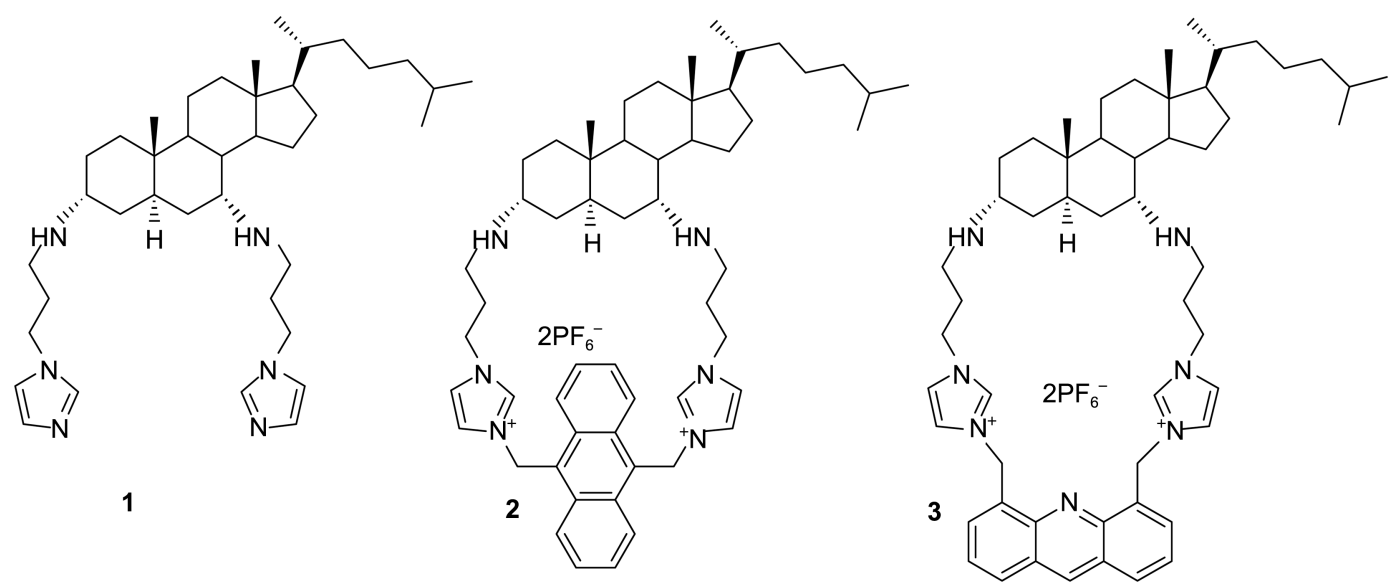

Figure 1. Structures of cholestane-based receptors 1, 2, and 3.

"This paper is dedicated to Professor Eun Lee on the occasion of his honourable retirement. 
2 was bridged with 9,10-dimethyleneanthracene and synthesized: its binding study was also evaluated through UV and fluorescence spectra with various anions in dry and aqueous $\mathrm{CH}_{3} \mathrm{CN} .{ }^{10}$ Receptor 2 showed the highest selectivity toward dihydrogen phosphate in dry $\mathrm{CH}_{3} \mathrm{CN}$ and with hydrogen pyrophosphate in aqueous $\mathrm{CH}_{3} \mathrm{CN}$.

In this paper, the observation of a new fluorescent acridineimidazolium cholestane based receptor 3, as shown in Figure 1 , bridged with 4,5-dimethyleneacridine for recognition of anions is reported. Cholestane-imidazolium cyclic receptor $\mathbf{3}$ was designed in order to increase the cavity size of receptor 2, and fit hydrogen pyrophosphate more selectively. The binding behaviour of receptor 3 by UV-vis and fluorescence spectroscopy toward various anions is described herein.

\section{Results and Discussion}

The acridine-imidazolium-based cholestane receptor 3 was prepared as shown in Scheme 1. Compound 1 was obtained through a one-step reductive amination of $5 \alpha$-cholestane-3,7dione with 3-aminopropylimidazole as described in our previous paper. ${ }^{8}$ The subsequent reaction of 1 with 4,5-bis (bromomethyl)acridine ${ }^{11}$ under reflux in $\mathrm{CH}_{3} \mathrm{CN}$ for $12 \mathrm{~h}$

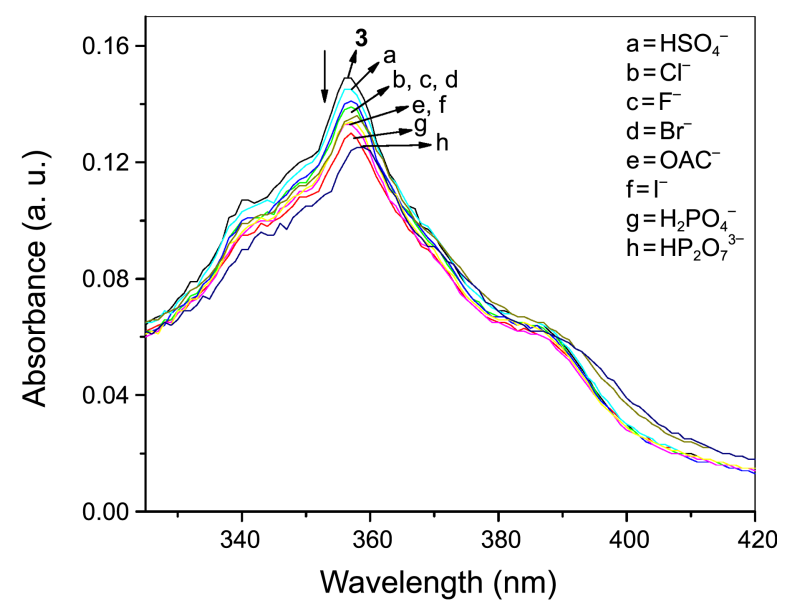

Figure 2. UV-vis changes of $3(20 \mu \mathrm{M})$ with 10 equiv of $\mathrm{F}^{-}, \mathrm{Cl}^{-}$, $\mathrm{Br}^{-}, \mathrm{I}^{-}, \mathrm{OAc}^{-}, \mathrm{HSO}_{4}^{-}, \mathrm{H}_{2} \mathrm{PO}_{4}^{-}$, and $\mathrm{HP}_{2} \mathrm{O}_{7}^{3-}$ in dry $\mathrm{CH}_{3} \mathrm{CN}$. gave the corresponding bromide salt of $\mathbf{3}$. Treatment of the latter with a saturated solution of potassium hexafluorophosphate in water provided the corresponding $\mathrm{PF}_{6}$ salt of 3 . The ${ }^{1} \mathrm{H}$ and ${ }^{13} \mathrm{C}$ NMR and HR mass confirmed the structure of 3 .

The recognition and binding properties of $\mathbf{3}$ with a series
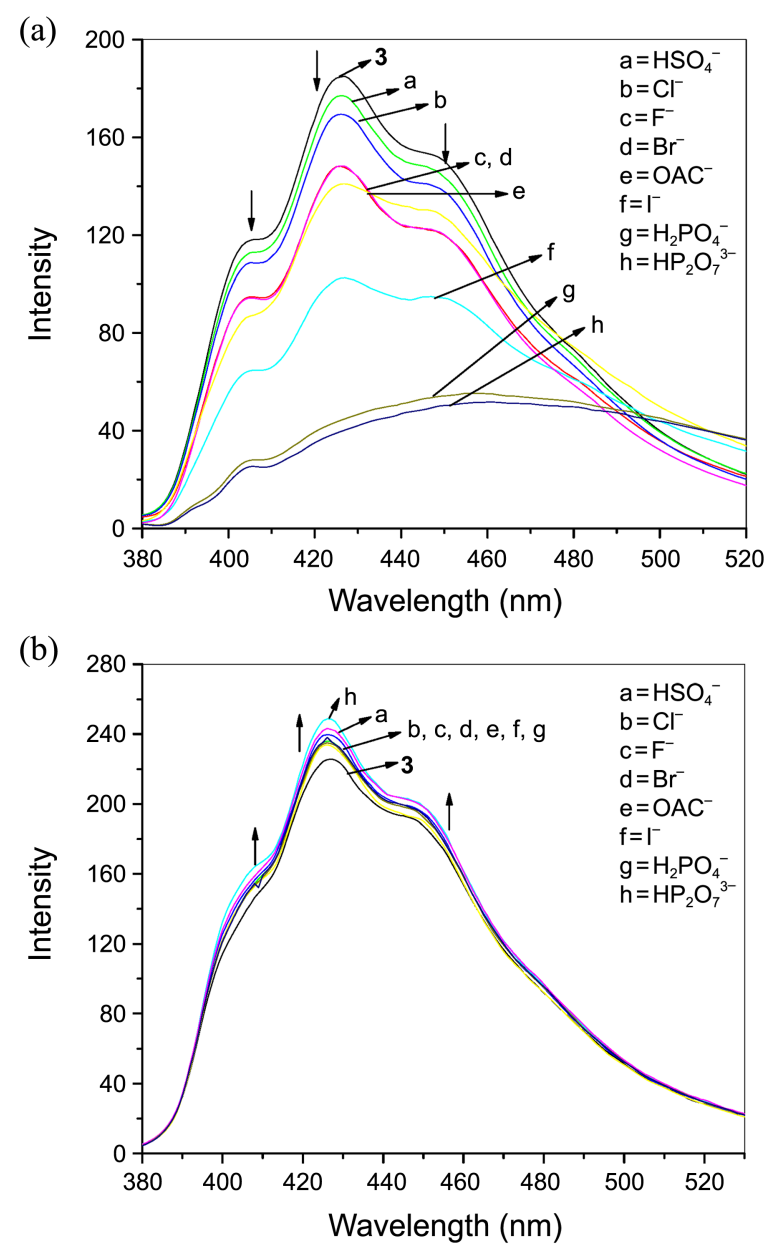

Figure 3. Fluorescence changes of $\mathbf{3}(10 \mu \mathrm{M})$ upon addition of 10 equiv of $\mathrm{F}^{-}, \mathrm{Cl}^{-}, \mathrm{Br}^{-}, \mathrm{I}^{-}, \mathrm{OAc}^{-}, \mathrm{HSO}_{4}^{-}, \mathrm{H}_{2} \mathrm{PO}_{4}^{-}$, and $\mathrm{HP}_{2} \mathrm{O}_{7}{ }^{3-}$ in (a) dry $\mathrm{CH}_{3} \mathrm{CN}$. $\left(\lambda_{\mathrm{ex}}=356 \mathrm{~nm}\right)$; (b) $10 \% \mathrm{H}_{2} \mathrm{O}$ in $\mathrm{CH}_{3} \mathrm{CN}$ at pH $7.4(10$ $\mathrm{mM}$ HEPES) $\left(\lambda_{\mathrm{ex}}=356 \mathrm{~nm}\right)$.
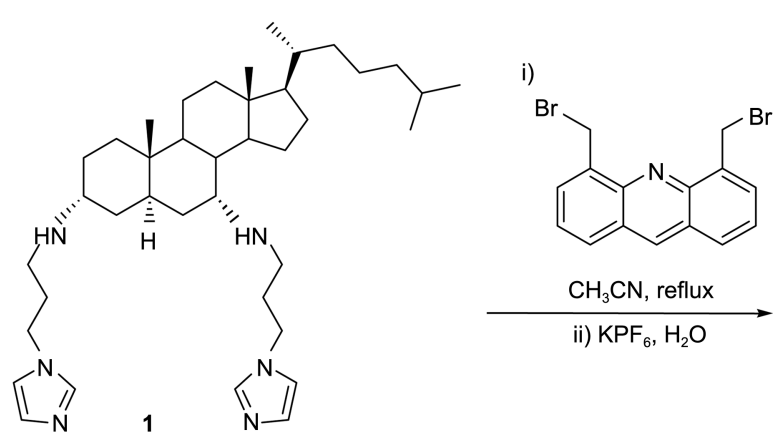

Scheme 1. Synthesis of the acridine-imidazolium-based cholestane receptor 3.

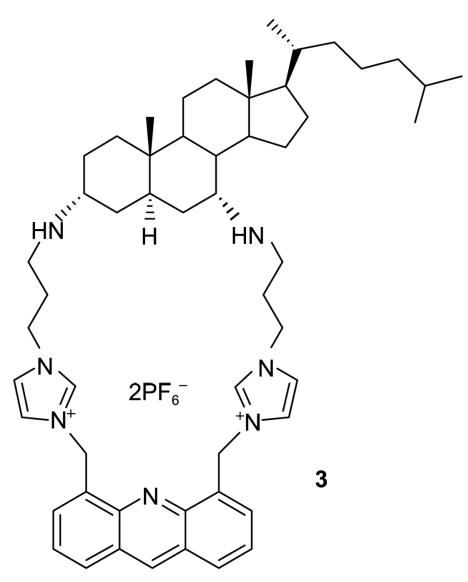


of anions, such as $\mathrm{F}^{-}, \mathrm{Cl}^{-}, \mathrm{Br}^{-}, \mathrm{I}^{-}, \mathrm{OAc}^{-}, \mathrm{HSO}_{4}^{-}, \mathrm{H}_{2} \mathrm{PO}_{4}^{-}$, and $\mathrm{HP}_{2} \mathrm{O}_{7}{ }^{3-}$ as their TBA salts, were assessed using $\mathrm{UV}$ and fluorescence spectroscopy in dry $\mathrm{CH}_{3} \mathrm{CN}$. Upon addition of 10 equiv of various anions into receptor $\mathbf{3}$, comparably more quenching was observed with $\mathrm{HP}_{2} \mathrm{O}_{7}{ }^{3-}$ and $\mathrm{H}_{2} \mathrm{PO}_{4}^{-}$ions as compared to other anions without showing any other significant changes in UV-vis absorption spectra as shown in Figure 2. Spectral changes of $\mathbf{3}$ upon the addition of various anions to those transitions within the absorption spectra did not change significantly due the acridine moiety, implying that there was not much ground state interaction between the fluorophore and the receptor.

In contrast, the changes in the fluorescence emission spectra are dramatic, as can be seen for $\mathbf{3}$ when 10 equiv of various anions is added (Fig. 3a). When a solution of $\mathbf{3}$ in dry $\mathrm{CH}_{3} \mathrm{CN}$ was excited at $356 \mathrm{~nm}$, the characteristic emissions for acridine were observed at 402, 426 , and $447 \mathrm{~nm}$ and 'switched off' to different extents in the presence of various anions. The addition of 10 equiv of $\mathrm{HP}_{2} \mathrm{O}_{7}{ }^{3-}$ and $\mathrm{H}_{2} \mathrm{PO}_{4}^{-}$ions in receptor 3 caused $70 \%$ quenching whereas the addition of $\mathrm{I}^{-}, \mathrm{OAc}^{-}, \mathrm{F}^{-}$, $\mathrm{Br}^{-}$ions induced relatively smaller quenching effects as compared to that of $\mathrm{HP}_{2} \mathrm{O}_{7}^{3-}$ and $\mathrm{H}_{2} \mathrm{PO}_{4}^{-}$ions. Fluorescence emissions were quenched upon $\mathrm{HP}_{2} \mathrm{O}_{7}{ }^{3-}$ and $\mathrm{H}_{2} \mathrm{PO}_{4}^{-}$ion

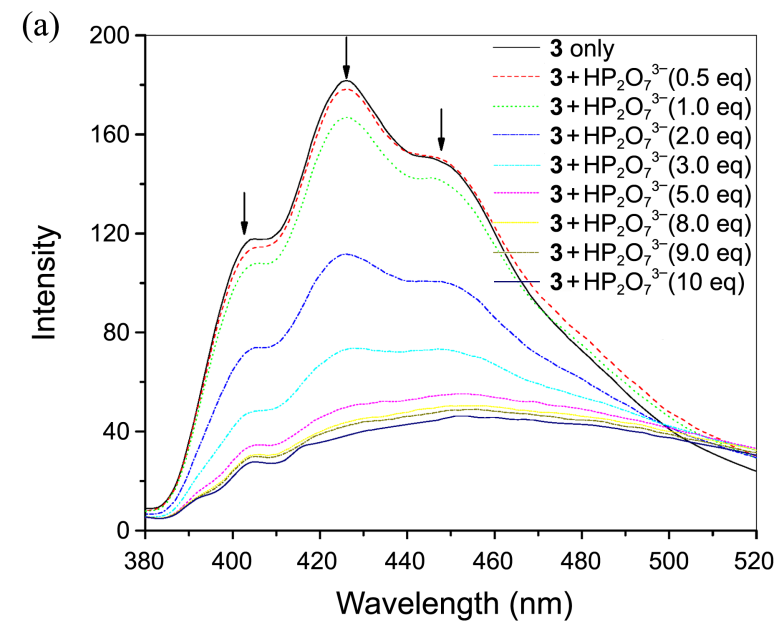

(b)

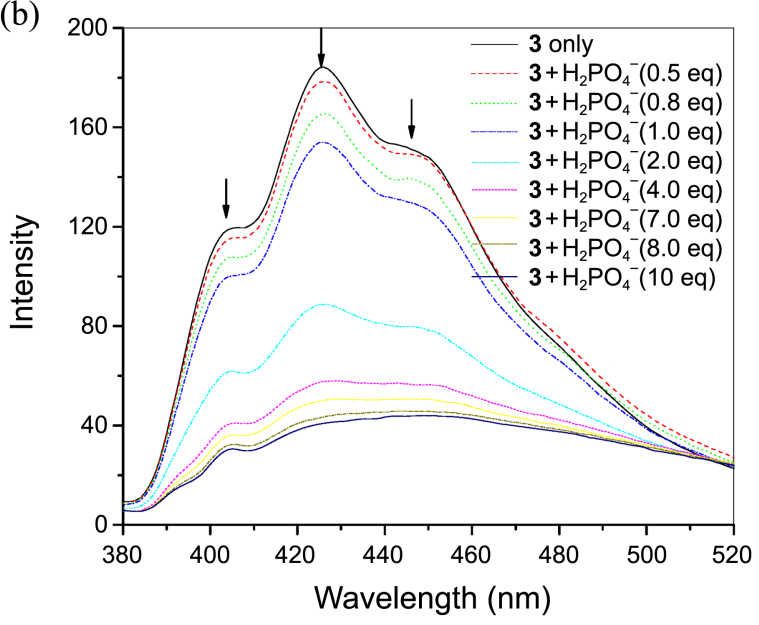

Figure 4. Changes in fluorescence spectra of $3(10 \mu \mathrm{M})$ in dry $\mathrm{CH}_{3} \mathrm{CN}$ with; (a) $\mathrm{HP}_{2} \mathrm{O}_{7}{ }^{3-}$ and (b) $\mathrm{H}_{2} \mathrm{PO}_{4}^{-}\left(\lambda_{\text {ex }}=356 \mathrm{~nm}\right)$. recognition with no significant changes in the structure of the emission bands (Fig. 4). The fact that $\mathrm{HP}_{2} \mathrm{O}_{7}{ }^{3-}$ and $\mathrm{H}_{2} \mathrm{PO}_{4}{ }^{-}$ anion gave rise to significant quenching indicates that the resulting receptor-anion complex was participating in photoinduced electron transfer (PET) quenching phenomenon. This quenching was the result of the formation of an electron rich receptor-anion complex, which in turn enhanced the free energy of PET quenching from the receptor to the acridine excited state and the emission was 'switched off'. A UV-vis study of 3 in $10 \%$ aqueous $\mathrm{CH}_{3} \mathrm{CN}$ did not show any remarkable results, whereas a comparably higher enhancement in intensity with hydrogen pyrophosphate was observed in other anions in the fluorescence spectra of $\mathbf{3}$ as shown in Figure $3 \mathrm{~b}$.

To confirm the interactions and binding constants between 3 with selective anions, titration experiments were conducted through a fluorescence study in dry $\mathrm{CH}_{3} \mathrm{CN}$. Figure 4 shows the fluorescence titration spectra of $\mathbf{3}$ with various concentrations (0-10 equiv) of $\mathrm{HP}_{2} \mathrm{O}_{7}{ }^{3-}$ and $\mathrm{H}_{2} \mathrm{PO}_{4}^{-}$ions. The 1:1 stoichiometry of $\mathrm{HP}_{2} \mathrm{O}_{7}{ }^{3-}$ and $\mathrm{H}_{2} \mathrm{PO}_{4}^{-}$ions binding with 3 was confirmed by a fluorescence Job's plot (Fig. 5).

From the fluorescent titration, the binding constants of $\mathbf{3}$ with $\mathrm{HP}_{2} \mathrm{O}_{7}{ }^{3-}, \mathrm{H}_{2} \mathrm{PO}_{4}^{-}, \mathrm{I}^{-}, \mathrm{OAc}^{-}, \mathrm{F}^{-}, \mathrm{Cl}^{-}$, and $\mathrm{Br}^{-}$were calculated to be $1.5 \times 10^{4} \mathrm{M}^{-1}, 1.1 \times 10^{4} \mathrm{M}^{-1}, 4.2 \times 10^{2} \mathrm{M}^{-1}$,
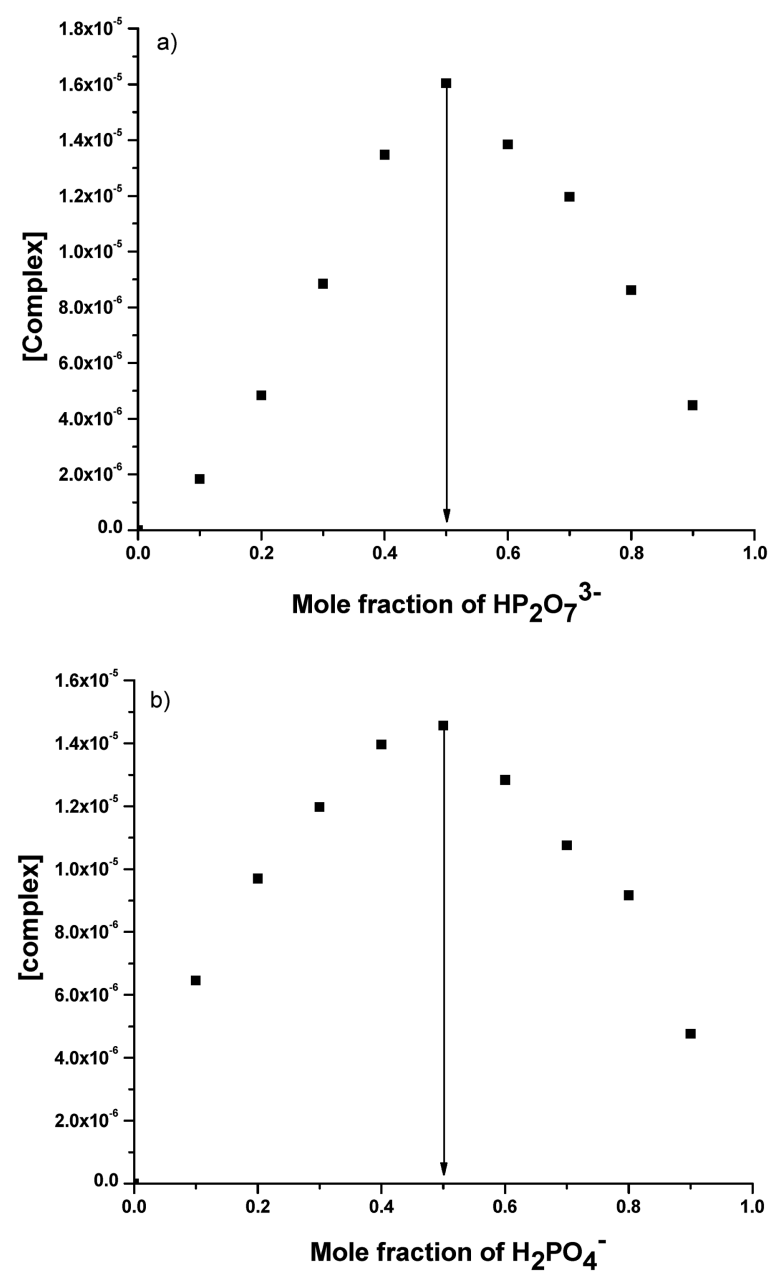

Figure 5. Fluorescence Job's plot of $\mathbf{3}$ with (a) $\mathrm{HP}_{2} \mathrm{O}_{7}{ }^{3-}$ and (b) $\mathrm{H}_{2} \mathrm{PO}_{4}^{-}$in dry $\mathrm{CH}_{3} \mathrm{CN}$ measured at $356 \mathrm{~nm}$. 
Table 1. Binding constants $K_{\mathrm{a}}\left(\mathrm{M}^{-1}\right)$ of 3 with anions in dry $\mathrm{CH}_{3} \mathrm{CN}$ at $298 \mathrm{~K}$

\begin{tabular}{cc}
\hline Anions $^{a}$ & $\mathrm{Ka}\left(\mathrm{M}^{-1}\right)^{b}$ \\
\hline $\mathrm{HP}_{2} \mathrm{O}_{7}^{3-}$ & $1.5 \times 10^{4}$ \\
$\mathrm{H}_{2} \mathrm{PO}_{4}{ }^{-}$ & $1.1 \times 10^{4}$ \\
$\mathrm{OAc}^{-}$ & $2.7 \times 10^{2}$ \\
$\mathrm{~F}^{-}$ & $1.1 \times 10^{2}$ \\
$\mathrm{Cl}^{-}$ & $7.1 \times 10^{1}$ \\
$\mathrm{Br}^{-}$ & $8.2 \times 10^{1}$ \\
$\mathrm{I}^{-}$ & $4.2 \times 10^{2}$ \\
$\mathrm{HSO}_{4}^{-}$ & $\mathrm{NC}$ \\
\hline
\end{tabular}

${ }^{a}$ Anions were used as their TBA salts. ${ }^{b}$ Error limit $<15 \%$. NC $=$ Not calculated.

(a)

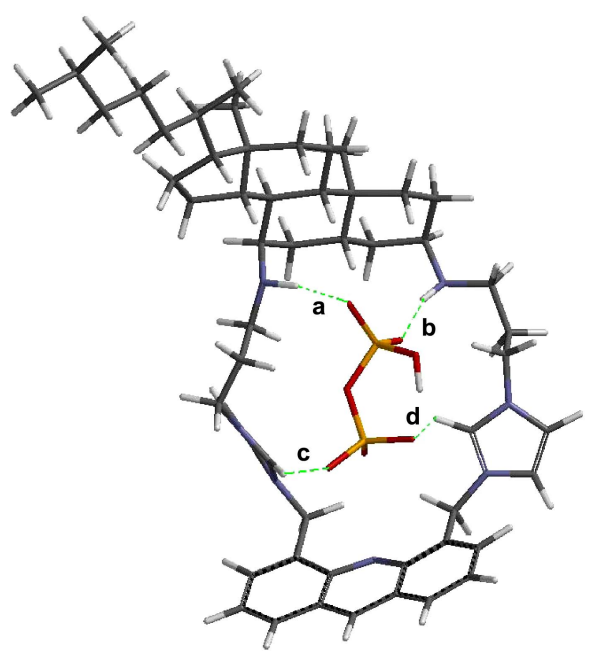

(b)

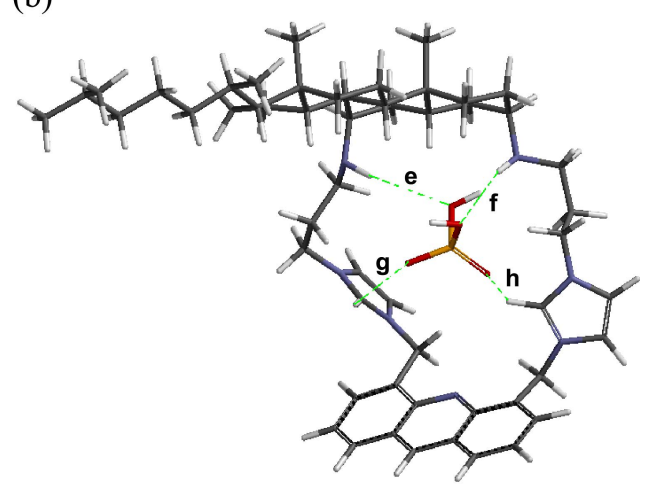

Figure 6. Energy minimized structures of (a) $3-\mathrm{HP}_{2} \mathrm{O}_{7}{ }^{3-}$ and (b) 3$\mathrm{H}_{2} \mathrm{PO}_{4}^{-}$.

$2.7 \times 10^{2} \mathrm{M}^{-1}, 1.1 \times 10^{2} \mathrm{M}^{-1}, 8.2 \times 10^{1} \mathrm{M}^{-1}$, and $7.1 \times 10^{1} \mathrm{M}^{-1}$, respectively (error limit $<15 \%$ ) as depicted in Table $1 .{ }^{12}$ The binding constant of $\mathrm{HSO}_{4}{ }^{-}$was not calculated due to inconsistency in fluorescence intensity. The binding constant of $\mathbf{3}$ with $\mathrm{HP}_{2} \mathrm{O}_{7}{ }^{3-}$ in aqueous $\mathrm{CH}_{3} \mathrm{CN}\left(9.5 \times 10^{2} \mathrm{M}^{-1}\right)$ was found to be two fold less than in dry $\mathrm{CH}_{3} \mathrm{CN}$.

In order to understand the nature, as well as the binding mode of receptor 3 with a guest species molecule studied in the present case, a molecular mechanics calculation was carried out. Geometries of all compounds involved were subject to optimization at the Hartree-Fock 3-21G (*) level using Spartan 04 software. ${ }^{13}$ It is evident from the optimized geometry of the complex of $\mathbf{3}$ in Figure $6, \mathrm{HP}_{2} \mathrm{O}_{7}{ }^{3-}$ was found to be more strongly bonded through $\mathrm{N}-\mathrm{H}^{\cdots} \mathrm{O}$ as a hydrogen bond, and the distance for $\mathrm{HP}_{2} \mathrm{O}_{7}{ }^{3-}$ was shorter than that of the $\mathrm{H}_{2} \mathrm{PO}_{4}{ }^{-}$ion. Both amino groups at $\mathrm{C} 3$ and $\mathrm{C} 7$ as well as the imidazolium $\mathrm{H}-2$ protons form hydrogen bonds through $\mathrm{N}-\mathrm{H}^{\cdots} \mathrm{O}-\mathrm{H}$ and $\mathrm{C}-\mathrm{H}^{+\cdots} \mathrm{O}^{-}$bonds. The distance observed in the hydrogen bond interactions were $a=1.85 \AA, b=$ $1.74 \AA, c=2.13 \AA$, and $d=2.34 \AA$ for $\mathrm{HP}_{2} \mathrm{O}_{7}{ }^{3-}$ and $e=2.34 \AA$, $f=2.16 \AA, g=2.29 \AA$, and $h=2.18 \AA$ for $\mathrm{H}_{2} \mathrm{PO}_{4}^{-}$, respectively.

In conclusion, we have synthesized a new fluorescent acridine-imidazolium cholestane based receptor $\mathbf{3}$ as an anion sensor, which showed the highest selectivity toward the $\mathrm{HP}_{2} \mathrm{O}_{7}{ }^{3-}$ ion through hydrogen bonding interactions. The highest selectivity of receptor 3 toward hydrogen pyrophosphate rather than dihydrogen phosphate might be caused by its improved cavity size and geometry due to its proper inclusion of spacers.

\section{Experimental Section}

Synthesis of Receptor 3. A solution of 4,5-bis(bromomethyl) acridine (30 mg, $1 \mathrm{mmol})$ and $\mathbf{1}(50 \mathrm{mg}, 1 \mathrm{mmol})$ in $\mathrm{CH}_{3} \mathrm{CN}$ $(15 \mathrm{~mL})$ was refluxed for $12 \mathrm{~h}$. After the work-up, the residue was dissolved in $20 \mathrm{~mL}$ of water and excess of $\mathrm{KPF}_{6}$ was added. The resulting mixture was stirred for $1 \mathrm{~h}$ at room temperature. The precipitate was then filtered and washed with water and ethanol subsequently to give $65 \mathrm{mg}$ of analytically pure product (72\%). mp $164-166{ }^{\circ} \mathrm{C}$; ${ }^{1} \mathrm{H}$ NMR $\left(\mathrm{CD}_{3} \mathrm{CN}\right) \delta 0.64\left(\mathrm{~s}, 3 \mathrm{H}, 18-\mathrm{CH}_{3}\right), 0.77\left(\mathrm{~s}, 3 \mathrm{H}, 19-\mathrm{CH}_{3}\right), 0.87$ $\left(\mathrm{d}, J=6.6 \mathrm{~Hz}, 3 \mathrm{H}, 26-\mathrm{CH}_{3}\right), 0.88\left(\mathrm{~d}, J=6.6 \mathrm{~Hz}, 3 \mathrm{H}, 27-\mathrm{CH}_{3}\right)$, $0.91\left(\mathrm{~d}, J=7.4 \mathrm{~Hz}, 3 \mathrm{H}, 21-\mathrm{CH}_{3}\right), 1.93-1.95$ (m, 4H, $\mathrm{HNCH}_{2-}$

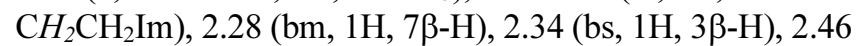
(m, 4H, $\mathrm{HNCH}_{2} \mathrm{CH}_{2} \mathrm{CH}_{2} \mathrm{Im}$ ), 2.99 (bs, 1H, NH), 3.91 (bm, 1H, $\mathrm{NH})$ ), 4.24 (m, 4H, $\mathrm{HNCH}_{2} \mathrm{CH}_{2} \mathrm{CH}_{2} \mathrm{Im}$ ), 5.99 (s, 4H, Acr$\mathrm{CH}_{2}$-Im), 6.96 and 6.98 (s, 1H, Im H-5), 7.04 and 7.11 (s, 2H, Im H-4), 7.42 (dd, $J=6.8,8.4 \mathrm{~Hz}, 2 \mathrm{H}, \mathrm{Acr} \mathrm{H}-2), 7.99$ (d, $J=$ $6.3 \mathrm{~Hz}, 2 \mathrm{H}$, Acr H-1), 8.26 (d, $J=8.4 \mathrm{~Hz}, 2 \mathrm{H}$, Acr H-3), 8.43 and 8.54 (s, 1H, Im H-2), 9.17 (s, 1H, Acr H-4); ${ }^{13} \mathrm{C}$ NMR $\left(\mathrm{CDCl}_{3}\right) \delta 12.5,13.6,16.7,18.5,19.8,22.2,22.8,23.6,23.7$, 23.9, 24.1, 28.1, 28.2, 28.5, 30.4, 30.6, 31.6, 32.0, 35.9, 36.4, 38.9, 39.6, 39.8, 42.9, 43.4, 43.9, 44.6, 45.4, 46.0, 46.3, 47.6, $50.2,50.6,52.7,54.6,124.5,125.8,127.6,128.2,130.6$, $132.8,133.5,136.7,139.8,146.9$; HR-mass Calcd. for $\left(\mathrm{C}_{54} \mathrm{H}_{77^{-}}\right.$ $\left.\mathrm{F}_{12} \mathrm{~N}_{7} \mathrm{P}_{2}^{2}-\mathrm{PF}_{6}\right)^{+}$968.5882, Found: $m / z 968.5885\left(\mathrm{M}-\mathrm{PF}_{6}\right)^{+}$.

Preparation of Fluorometric Anion Titration Solutions. The host 3 was prepared as $10 \mu \mathrm{M}$ stock solution in $\mathrm{CH}_{3} \mathrm{CN}$. All anions used in this report were prepared by adding $10 \mathrm{~mL}$ of stock solution of the host compound. After shaking for several minutes, the work solution could be measured immediately. For all measurements excited at $356 \mathrm{~nm}$, emission was measured at $426 \mathrm{~nm}$. Both the excitation and emission slits width were $5 \mathrm{~nm}$.

Acknowledgments. This research was supported by the 
National Research Foundation of Korea (NRF-2010-0010070).

\section{References and Notes}

1. (a) Gale, P. A. Chem. Commun. 2011, 82. (b) Gale, P. A. Chem. Soc. Rev. 2009, 38, 520. (c) Yoon, J.; Kim, S. K.; Singh, N. J.; Kim, K. S. Chem. Soc. Rev. 2006, 35, 355. (d) Gale, P. A. Coord. Chem. Rev. 2003, 240, 191. (e) Beer, P. D.; Gale, P. A. Angew. Chem. Int. Ed. 2001, 40, 486. (f) Schmidtchen, D.; Berger, M. Chem. Rev. 1997, 97, 1609. (g) Beer, P. D.; Smith, D. K. Prog. Inorg. Chem. 1997, 46, 1.

2. (a) Xu, Z.; Kim, S. K.; Yoon, J. Chem. Soc. Rev. 2010, 39, 1457: references cited therein. (b) Chen, X.; Kang, S.; Kim M. J.; Kim, J.; Kim, Y. S.; Kim, H.; Chi, B.; Kim S.-J.; Lee, J. Y.; Yoon, J. Angew. Chem. Int. Ed. 2010, 49, 1422. (c) Kim, S. K.; Seo, D.; Han, S. J.; Son, G.; Lee, I.-J.; Lee, C.; Lee, K. D.; Yoon, J. Tetrahedron 2008, 64, 6402. (d) Xu, Z.; Kim, S.; Lee, K.-H.; Yoon, J. Tetrahedron Lett. 2007, 48, 3797. (e) Kim, S. K.; Singh, N. J.; Kwon, J.; Hwang, I.-C.; Park, S. J.; Kim, K. S.; Yoon, J. Tetrahedron 2006, 62, 6065. (f) Chellappan, K.; Singh, N. J.; Hwang, I.-C.; Lee, J. W.; Kim, K. S. Angew. Chem. Int. Ed. 2005, 44, 2899. (g) In, S.; Kang, J. Bull. Korean Chem. Soc. 2005, 26, 1121. (h) Baker, M. V.; Bosnich, M. J.; Brown, D. H.; Byrne, L. H.; Hesler, V. J.; Skelton, B. W.; White, A. H.; Williams, C. C. J. Org. Chem. 2004, 69, 7640. (i) Frank, M.; Maas, G.; Schatz, J. Eur. J. Org. Chem. 2004, 607.

3. (a) Brotherhood, P. R.; Davis, A. P. Chem. Soc. Rev. 2010, 39, 3633. (b) Kumar, A.; Pandey, P. S. Org. Lett. 2008, 10, 165. (c) Davis, A. P. Coord. Chem. Rev. 2006, 250, 2939. (d) Kim, K. S.;
Kim, H.-S. Tetrahedron 2005, 61, 12366. (d) Kim, K. S.; Cho, N. J.; Kim, H.-S. Bull. Korean Chem. Soc. 2006, 27, 739. (e) Kim, K. S.; Jang, H.-S.; Kim, H.-S. Bull. Korean Chem. Soc. 2006, 27, 1445. (f) Davis, A. P. Chem. Soc. Rev. 1993, 22, 243.

4. Spector, A. A; Yorek, M. A. J. Lipid Res. 1985, 26, 1015.

5. Roux, C.; Wolf, C.; Mulliez, N.; Gaoua, W.; Cormier, V.; Chevy, F.; Citadelle, D. Am. J. Clin. Nutr. 2000, 71, 1270.

6. (a) Kim, H.-S.; Choi, B. S.; Kwon, K. C.; Lee, S. O.; Kwak, H. J.; Lee, C. H. Bioorg. Med. Chem. 2000, 8, 2059. (b) Kim, H.-S.; Kwon, K.-C.; Kim, K. S.; Lee, C. H. Bioorg. Med. Chem. Lett. 2001, 11, 3065. (c) Khan, S. N.; Baeo, S.-Y.; Kim, H.-S. Tetrahedron Lett. 2005, 46, 7675. (d) Khan, S. N.; Kim, H.-S.; Kim, B. J. Bioorg. Med. Chem. Lett. 2007, 17, 5139. (e) Khan, S. N.; Cho, N. J.; Kim, H.-S. Tetrahedron Lett. 2007, 48, 5189. (f) Khan, S. N.; Jung, Y. M.; Kim, B. J.; Cho, H.; Lee, J.; Kim, H.-S. Bioorg. Med. Chem. Lett. 2008, 18, 2558.

7. Hussain, S.; Brotherhood, P. R.; Judd, L. K.; Davis, A. P. J. Am. Chem. Soc. 2011, 133, 1614.

8. Ahmad, M. W.; Jung, Y. M.; Khan, S. N.; Kim, H.-S. Bull. Korean Chem. Soc. 2009, 30, 2101.

9. Jadhav, J. R.; Ahmad, M. W.; Kim, H.-S. Tetrahedron Lett. 2010, $51,5954$.

10. Jadhav, J. R.; Bae, C.-H.; Kim, H.-S. Tetrahedron Lett. 2011, 52, 1623.

11. Chiron, J.; Galy, J.-P. Synlett 2003, 15, 2349.

12. Thordarson, P. Chem. Soc. Rev. 2011, 40, 1305.

13. Energy minimization was carried out using Spartan 04 for Windows (Wavefunction, Inc.: Irvine, CA). 